\title{
INVESTIGATION OF CHARGE-DISCHARGE PROCESSES IN THE SPACECRAFT DETACHABLE CONNECTOR
}

\author{
R. E. Tikhomirov*, I. A. Maximov, D. A. Trofimchuk, V. V. Ivanov, S. V. Balashov \\ JSC “Academician M. F. Reshetnev” Information Satellite Systems” \\ 52, Lenin Str., Zheleznogorsk, Krasnoyarsk region, 662972, Russian Federation \\ *E-mail: tikhroman@gmail.com
}

\begin{abstract}
Modern spacecraft consists of structural materials with different electro-physical characteristics, and it causes the occurrence of charge-discharge processes on the spacecraft during interaction with the magnetospheric plasma. The study of this phenomena arising during the natural spacecraft charging and its influence on the onboard systems functioning is of great interest in the field of ensuring the stability of spacecraft under the space factors influence.

The paper presents the experimental results of charge-discharge processes occurring in detachable connectors during in-space exploitation after undocking the separating device and placing the spacecraft onto the orbital slot. For the determination of impact factors characteristics of electrostatic discharge and its potential effect on spacecraft board equipment the charge-discharge processes research methods with account of spacecraft equipment interfaces were designed. For modeling of electrostatic discharge in detachable connectors and its effects in technological circuits of spacecraft equipment the imitation loads were applied. These loads include input interface elements of spacecraft power convectors and onboard control complex.

The results show that the dielectric material of connector contact field can accumulate a charge to the value limited by the discharge on it. Discharge processes on the dielectric material induce interfering pulses in onboard cable harness and can have a significant impact on the work of onboard equipment. The obtained results are useful in spacecraft equipment designing in the sphere of interference immunity.
\end{abstract}

Keywords: electrostatic discharge, spacecraft charging, plasma, spacecraft detachable connector.

Сибирский журнал науки и технологий. 2018. Т. 19, № 2. С. 325-331

\section{ИССЛЕДОВАНИЕ ЗАРЯДНО-РАЗРЯДНЫХ ПРОЦЕССОВ НА ОТРЫВНОМ РАЗЬЕМЕ КОСМИЧЕСКОГО АППАРАТА}

\author{
Р. Е. Тихомиров*, И. А. Максимов, Д. А. Трофимчук, В. В. Иванов, С. В. Балашов \\ АО «Информационные спутниковые системы» имени академика М. Ф. Решетнёва» \\ Российская Федерация, 662972, г. Железногорск Красноярского края, ул. Ленина, 52 \\ *E-mail: tikhroman@gmail.com
}

\footnotetext{
В силу того, что современный космический аппарат состоит из конструкционных материалов с различными электрофизическими характеристиками, это приводит к возникновению зарядно-разрядных прочессов на космическом аппарате при взаимодействии с магнитосферной плазмой. Изучение явлений, возникающих в ходе натурной электризации космических аппаратов, и их влияния на работу бортовых систем представляет широкий интерес в области обеспечения стойкости космических аппаратов при воздействии факторов космического пространства.

Представлены результаты исследования зарядно-разрядных процессов, возникающих в ходе натурной эксплуатации космического аппарата на отрывных соединителях после расстыковки с устройством отделения $и$ вывода на орбитальную позищию. Для определения величины воздействующих факторов электростатического разряда и их потенциального влияния на бортовую аппаратуру была разработана методика исследований зарядно-разрядных процессов на отрывных соединителях с учетом реальных интерфейсов бортовой аппаратуры космического аппарата. Авторами использованы имитационные нагрузки для моделирования воздействия электростатического разряда на технологические иели отрывного соединителя, ведущие к бортовой аппаратуре. Использованы элементы входного интерфейса энергопреобразователя космического аппарата и бортового комплекса управления. Установлено, что контактное поле диэлектрического материала при воздействии магнитосферной плазмы способно эффективно накапливать электрический потенциал, ограниченный протеканием разрядных процессов. Разрядные процессы, протекающие на диэлектрике отрывного соединителя, индуцируют помеховые импульсы в бортовую кабельную сеть и способны оказать существенное влияние на ра-
} 
боту бортовой аппаратуры и стать причиной аномалий в ее работе. Определены параметры помеховых импульсов и их влияние на имитационные нагрузки, соответствующие бортовой аппаратуре.

Полученные результаты представляют значительный интерес и будут использованы при проектировании бортовой аппаратуры космического аппарата в части обеспечения ее помехозащищенности.

Ключевые слова: электризачия космических аппаратов, плазма, электростатический разряд, отрывной разъем.

\section{Doi: $10.31772 / 2587-6066-2018-19-2-325-331$}

Introduction. During the interaction of a spacecraft with the magnetosperic plasma operating on the final orbit many physical phenomena occur which particular characteristics depend on both plasma parameters and the spacecraft performance. First of all they depend on electrophysical properties of materials on the spacecraft surface as well as on its configuration. The discharge [1-4] on the spacecraft surface is able to exert the most significant influence on its operation. This process is due to the spacecraft charging $[5 ; 6]$.

During the final orbit insertion after undocking the separating device contact surfaces of the detachable connectors (OCMPC50Э, OCM PC50AЭ plugs) remain non-shielded and are exposed to the magnetosperic plasma with the following characteristics (in the worst case) [7]:

- electron density is $1.12 \mathrm{~cm}^{-3}$;

- electron energy is $1.2 \times 10^{4} \mathrm{eV}$;

- ion concentration is $0.236 \mathrm{~cm}^{-3}$;

- ion energy is $2.95 \times 10^{4} \mathrm{eV}$.

By the impact of the magnetosperic plasma on detachable connectors the outer non-shielded dielectric material (a dielectric contacting substance) can accumulate a charge and it causes discharging processes and interference current pulses injection in the circuits of the docked cable harness.

In the modern research and technical literature the problem of contacting surface charging in the detachable connectors as well as the impact of inducted interference pulses in circuits of the spacecraft board equipment plugged to these connectors is not investigated. Nevertheless, the problem of the board equipment and spacecraft charging effects immunity is one of the most important one. The interfering pulses in board cable harness inducted by discharging processes on the spacecraft dielectric materials may cause the essential abnormality of the equipment operation [8-11] and this is the reason how important the investigation in this field is.

Experimental method. The aim of testing the detachable connectors for charging factors impact is:

- to determine the charge-discharge process characteristics appearing on the connectors contact surface;

- to determine the interfering pulses characteristics in circuits of cable harness plugged to the connectors on one side and to the elements of a board equipment frontend module on the other side.

There were the following testing samples:

1. Cable harness "№ 1" with the length of $500 \mathrm{~mm}$ including relays RPS45 (modification ЯЛ0.452.081ТУ) as a load (imitation of technological circuits linking the detachable connector and the spacecraft control unit).

2. Cable assembly "№ 2" with the length of $500 \mathrm{~mm}$ including relays REK81 (modification
ИДЯУ.647611.002ТУ) as a load (imitation of technological circuits linking the detachable connector and the spacecraft control unit).

3. Cable assembly "№ 3" with the length of $500 \mathrm{~mm}$ including elements of a power board equipment front-end module of spacecraft power system as a load;

The test was carried out at the engineered workstation (fig. 1) including a vacuum unit, an E-beam emitter, a discharge parameter measuring system and a discharge process video registration system.

A $70 \mathrm{keV}$ monoenergetic beam with current density $1 \mathrm{nA} / \mathrm{cm}^{2}$ was used for the imitation of magnetospheric plasma electron effect [9]. The impact was conducted in vacuum (chamber pressure is $\leq 10^{-6}$ torr). For the "worstcase" charging effect [3;12-15] the sample was cooled off to $-60{ }^{\circ} \mathrm{C}$ which corresponds the natural operating conditions. The further chilldown of the sample to lower temperatures makes no physical sense because of small changes of connector dielectric resistance and, as a consequence, their minimal influence on the charging process $[3 ; 4]$.

The following parameters of charge-discharge processes on the sample were controlled in operation:

a) maximum integral potential of the insulating contact surface of the detachable connector;

b) peak amplitude, duration, building-up time, interfering pulse frequency in circuits of cable harness;

c) peak amplitude, duration, building-up time, voltage interfering pulse frequency in circuits cable harness;

d) peak amplitude, duration, building-up time, interfering current pulse frequency in circuits of the harness external shield.

Measurements of parameters "b", "c" and "d" were taken simultaneously. The testing scheme is displayed on fig. 2 and 3.

During the test performance for the samples № 1 and 2 detachable connector contact leads were linked to the relay winding leads. For the samples 1 and 2 the test was carried out for two modes of switched relay circuit contacts - normally closed and normally opened ones. During the circuit adjustment for the samples 1 and 2 operational changes of switched relay circuit contacts were conducted by means of the pulse voltage injection whose value met the stated requirements for a relay.

During the test performance for the samples № 1 and 2 the relay contacts switching and the contact bounce potential were controlled. At the moment of electron beam impact on the detachable connector the constant voltage was applied at the switched relay circuit input and the measurement of the voltage magnitude at relay output dependence on time was taken by means of oscillograph. The contact bounce or switching mode changes were estimated in real time with help of oscillograph readings. 
Test based results. The attained results of the detachable connector charging test show that the insulating material of the connector contact field can effectively accumulate a charge due to electrojet current impact. The maximum value of insulating material electrostatic poten- tial attained during the test procedure was $1.6 \mathrm{kV}$ and was limited by discharging processes which were the source of interfering current pulses in circuits linked to the detachable connector. Such discharging processes are shown on fig. 4.

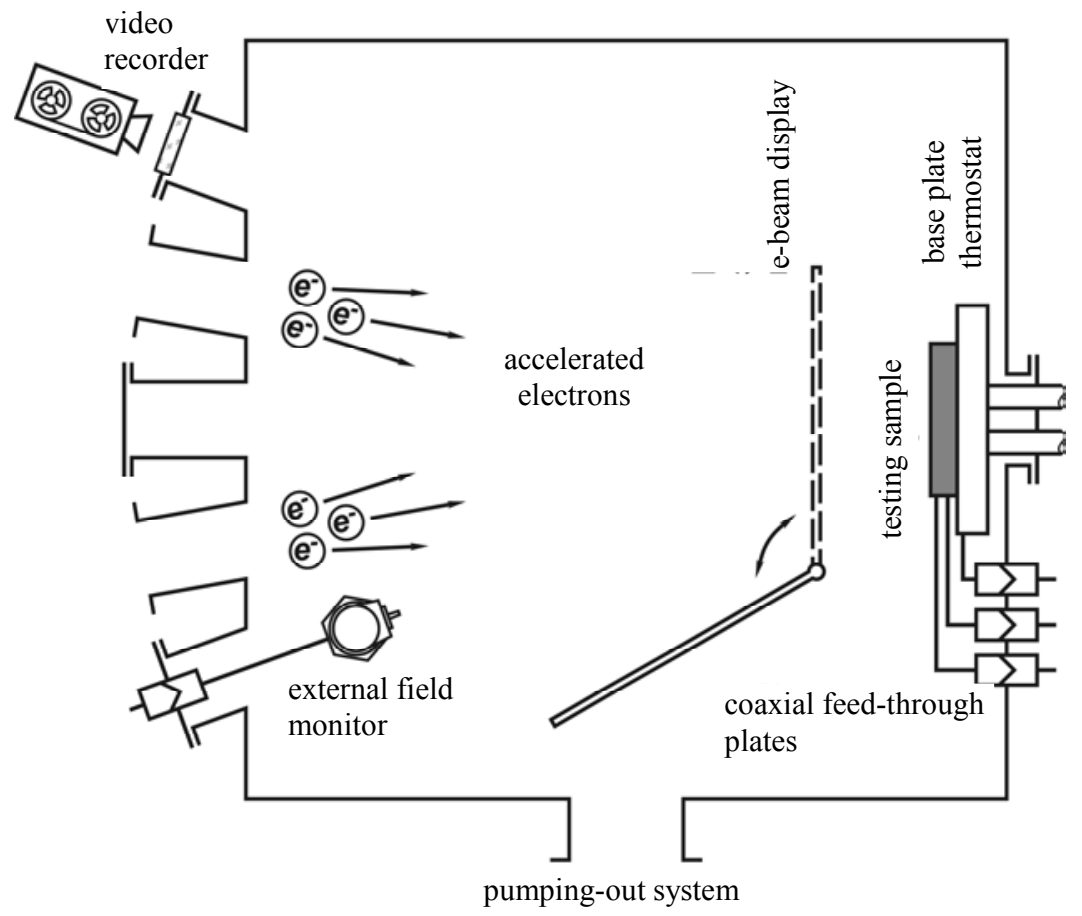

Fig. 1 Workstation scheme for tests

Рис. 1. Схема рабочего места испытаний

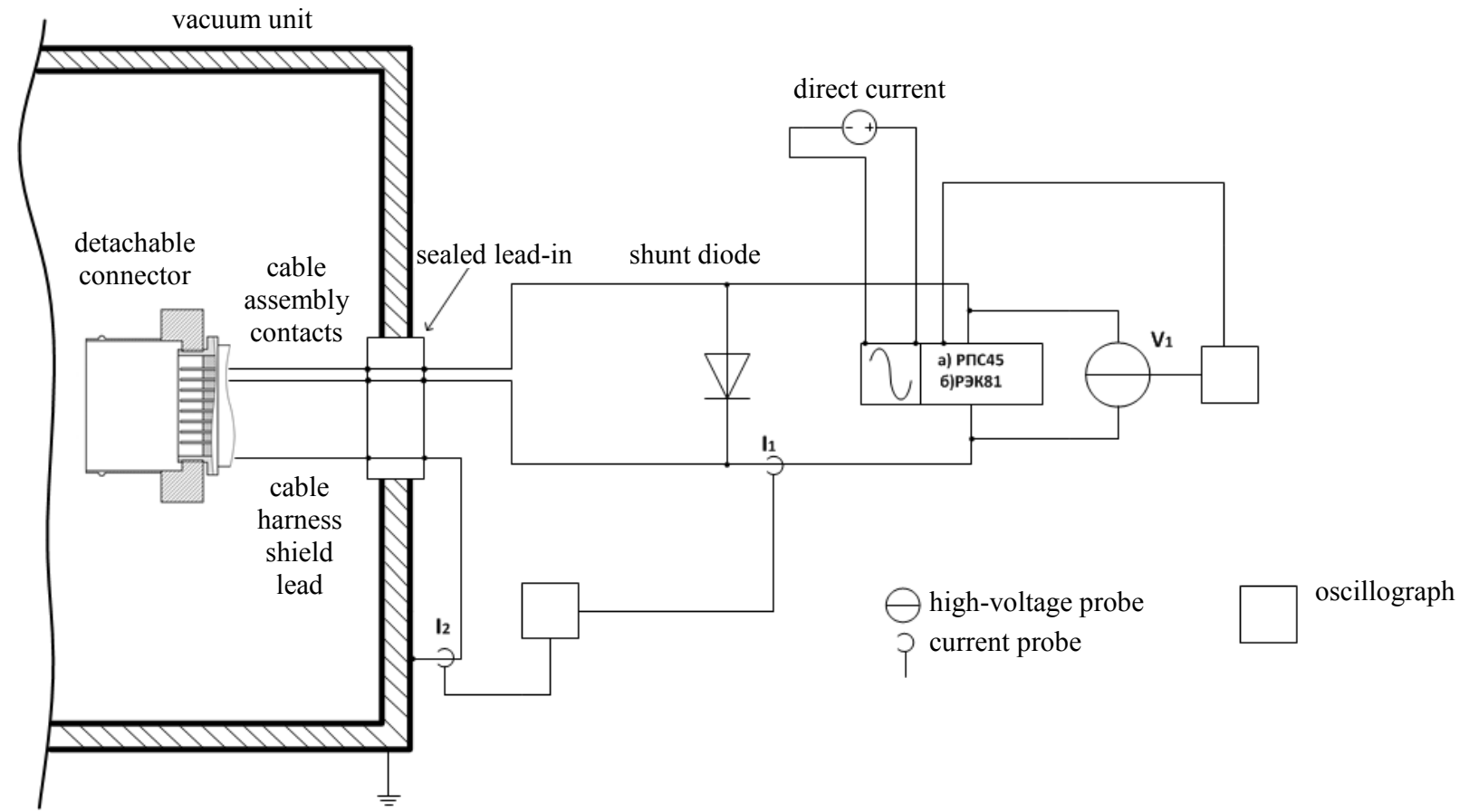

Fig. 2. The testing scheme for samples № 1 and 2

Рис. 2. Схема проведения испытаний для образцов № 1 и 2 


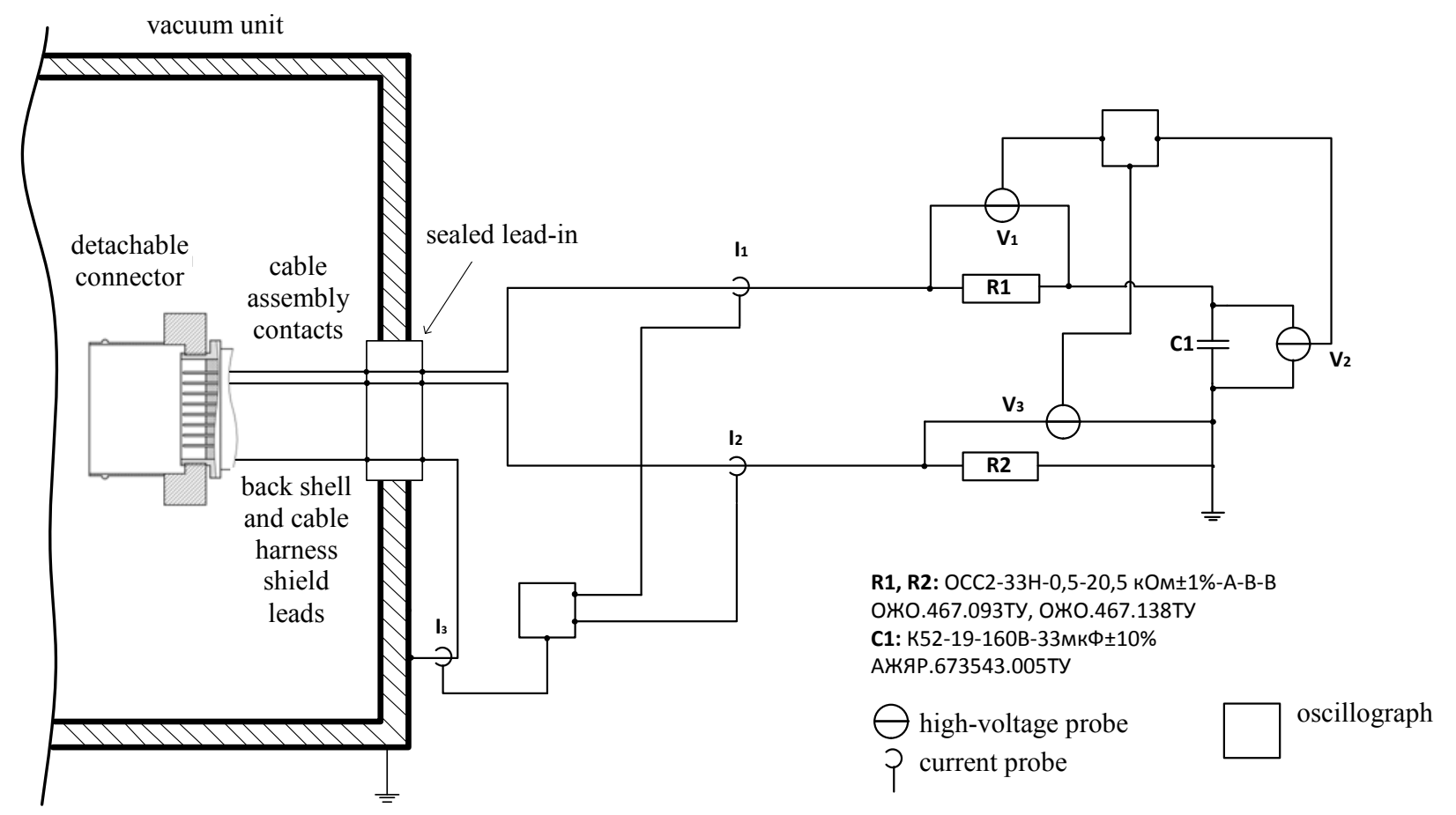

Fig. 3. The testing scheme for sample № 3

Рис. 3. Схема проведения испытаний для образца № 3
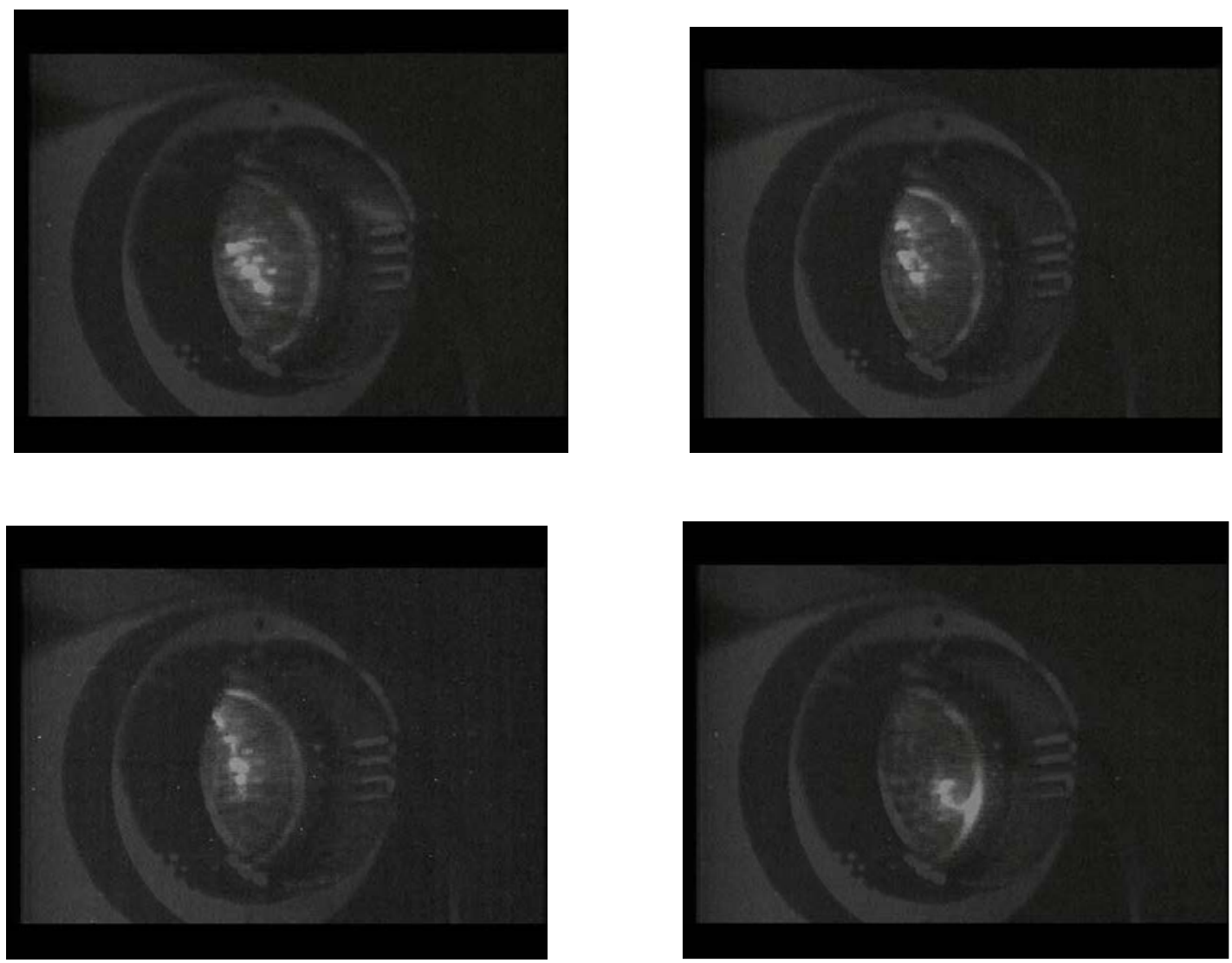

Fig. 4. Image of discharge pulses on the surface of connector isolation

Рис. 4. Вид разрядов на поверхности изолятора разъема 

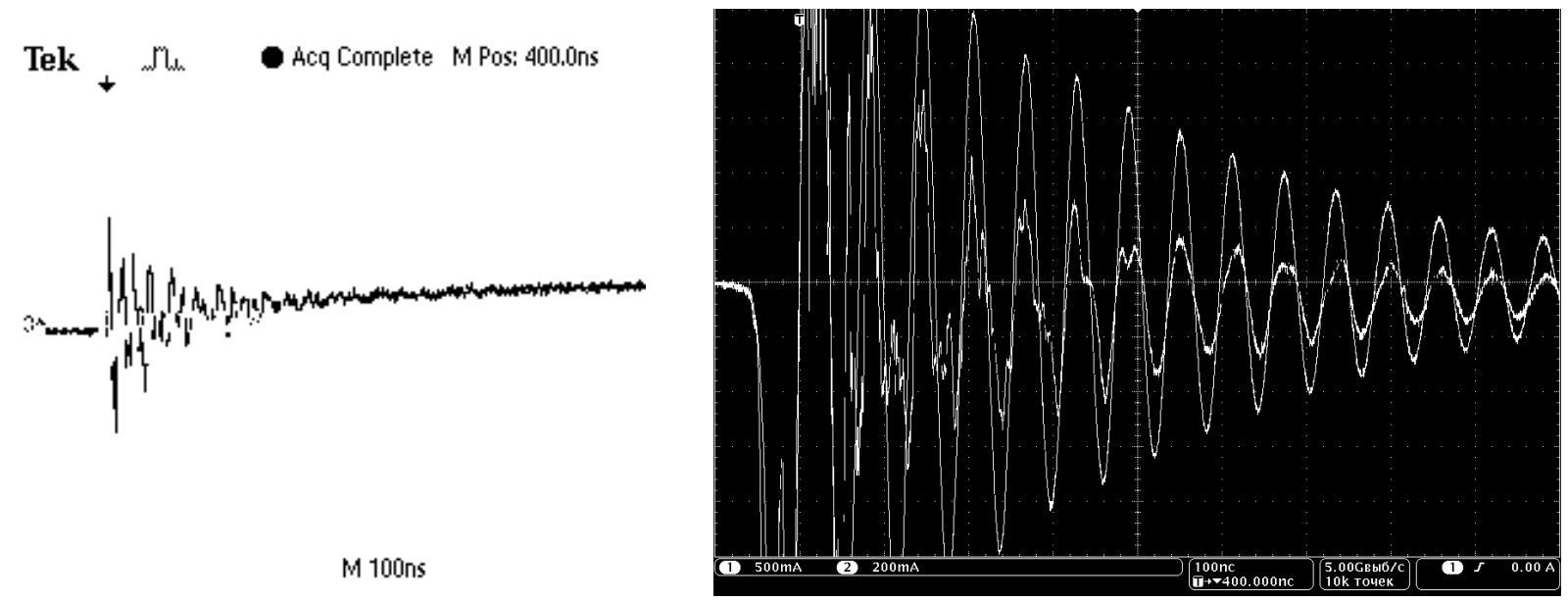

$a$

$b$

Fig. 5. Characteristic shapes of inducted pulses in samples electrical circuits: $a$-shapes of current pulses; $b$ - shapes of voltage pulses

Рис. 5. Характерная форма индуцированных помеховых импульсов в цепях образцов: $a$ - осциллограммы импульсов по напряжению; $\sigma$ - осциллограммы импульсов по току

Discharge pulses characteristics in circuits linked to the connector depend on the loads (board equipment elements and devices).

By imitation of technological circuits linking the detachable connector and the spacecraft power conditioning unit (fig. 3) the voltage values of interfering current pulses varied from 10 to $80 \mathrm{~V}$ and current value varied from $160 \mathrm{~mA}$ to $6.5 \mathrm{~A}$. Pulse duration time was within the range from $300 \mathrm{~ns}$ to $1.1 \mu \mathrm{s}$. Based on the obtained characteristics interfering pulse energy values vary from $0.5 \mu \mathrm{J}$ to $0.57 \mathrm{~mJ}$.

The obtained voltage values of interfered pulses in circuits of RPS45 relay winding were from 120 to $138 \mathrm{~V}$ and the current values were from 1.2 to $3 \mathrm{~A}$. Cable harness pulses duration time was less than $1 \mu \mathrm{s}$. Pulse energy was no more than $0.4 \mathrm{~mJ}$. Pulse voltage characteristics for REK81 relay were from 30 to $138 \mathrm{~V}$ and current ones were from 4.6 to 9 A. Pulse duration time was no more than 500 ns. Pulse energy was no more than 0.62 mJ. Distinctive pulse forms are shown on fig. 5 .

During the relay commutation control mode (for both RPS45 and REK81) it was estimated that interfering pulses in circuits can induce interference in the normally opened relay contact. The shape and duration time of this interference correlate to the pulses detected in winding contacts. In this case directed pulse amplitude in normally opened contacts is not higher than $10 \%$ of inducted pulse amplitude in the circuit of relay winding. During the test operation the impact of interfering pulses on the recorded values in normally closed contacts was not found.

It is necessary to point out that the shapes of inducted pulses in electrical circuits of two examined relay types are various. For RPS45 the pulses are splashes of positive polarity following by attenuation. For REK 81 the directed impulse in winding circuits is a damped sinusoid. This characteristic may be caused by various relay physical parameters having an effect on the discharge current flow process. Nevertheless, the amplitude and the energy of the interfering pulse is virtually the same for both types.

It is arguable that the detected interference in normally opened contacts of two relay types is an electromagnetic pickup and the change arrangement of relay contacts (closing and opening) by the interfering pulses impact in circuits of the winding is not available.

During the test performance the impact of electron flux density on charge-discharge processes in cable harness was estimated. For this purpose an impact was conducted by electron beam density $0.1 \mathrm{nA} / \mathrm{cm}^{2}$ (by electron energy $70 \mathrm{keV}$ ). It is found that the change of this beam characteristic has an impact only on charge-discharge processes intensity. With increase of beam density the charge-discharge processes intensity grows. An impact on the maximum potential of connector surface isolation and interfering pulse characteristics in circuits of cable harness by various types of loads is not available.

The obtained results correspond to the "worst case" of the charging factors impact in the circuit of onboard equipment linked to the detachable connector. For the test a cable of length $500 \mathrm{~mm}$ (standard cable length varies from 2 to $5 \mathrm{~m}$ ) was used. The increase of cable length can cause interference reduction.

Conclusion. The connector contact field isolation accumulates an electrostatic charge effectively by the impact of an electrojet current and its value is limited by charge processes on the isolation surface.

Charging processes on the connector contact field isolation induce interfering pulses in circuits of cable harness linked to the various types of loads which are appropriate to spacecraft onboard equipment. The maximum interfering pulse for the spacecraft power conditioning unit elements was $80 \mathrm{~V}$ (voltage value) and $6.5 \mathrm{~A}$ (current value). The pulse energy is $0.6 \mathrm{~mJ}$ by the duration time $1.1 \mu \mathrm{s}$. 
By imitation of technological circuits of the spacecraft control unit two relay types (RPS45 and REK81) were used as loads. The maximum levels of interfering pulses in circuits of relay winding were $138 \mathrm{~V}$ (voltage value) and 3 A (current value) for RPS45 and $138 \mathrm{~V}$ (voltage value) and 9 A (current value) for REK81. By the pulse duration time $1 \mu \mathrm{s}$ and $500 \mathrm{~ns}$ the energy was $0.4 \mathrm{~mJ}$ for RPS45 and $0.62 \mathrm{~mJ}$ for REK81.

The relay commutation control showed that interfering pulses in the circuit of the relay winding can induce pickups with the voltage amplitude from 7 to $25 \mathrm{~V}$ and with the duration time less than $1 \mu$ s on normally opened relay contacts. In this case changes of the contacts switching state of both types are not available.

The obtained results are of significant interest and can be used in spacecraft equipment designing in the sphere of interference immunity and proper functioning.

\section{References}

1. Maksimov I. A., Kochura S. G. Issledovaniye vliyaniya faktorov kosmicheskogo prostranstva i tekhnogennykh faktorov na kosmicheskiye apparaty, razrabotka metodov $i$ sredstv zashchity [Research of influence of factors of space and technogenic factors on spacecrafts, development of methods and means of protection]. Krasnoyarsk, SibSAU Publ., 2011, 182 p.

2. ECSS-E-ST-20-06C, Space engineering, Spacecraft charging, 2008, ESA Standart, 120 p.

3. Model kosmosa T. 2. Vozdeistvie kosmicheskoi sredy na materialy i oborudovanie kosmicheskikh apparatov [Space model. Vol. 2. Space environment influence on spacecraft materials and equipment]. Ed. M. I. Panashuka, L. S. Novikova. Moscow, CDU Publ., 2007, 1144 p.

4. Grafodatskiy O. S., Babkin G. V., Belinskiy V. N. et al. Nazemnyye stendovyye ispytaniya kosmicheskikh apparatov na stoykost' $k$ vozdeystviyu radiatsionnoy elektrizatsii [Ground-based bench tests of space vehicles for resistance to radiation radiation]. Korolev, TSNIIMash, GONTI-1 Publ., 1992, 157 p.

5. NASA-HDBK-4002A, Mitigating in-space charging effects - a guideline, 2011, NASA, $181 \mathrm{p}$.

6. MIL-STD-461, "Requirements for the control of electromagnetic interference characteristics of subsystems and equipment", 1999, US Department of Defense.

7. Garret H. B. The geosynchronous plasma environment, AIAA Paper 90-0289, 1999, 16 p.

8. Tikhomirov R. E., Maximov I. A., Trofimchuk D. A., Ivanov V. V., Balashov S. V. [Investigation of characteristics of electric field arising from electrostatic discharge]. Vestnik SibGAU. Vol. 17, No. 4, P. 1015-1019 (In Russ.).

9. Tikhomirov R. E., Trofimchuk D. A. et al. [Modeling of radiation electrization of spacecraft construction materials] Trudy Vserossiyskoy konferentsii studencheskikh nauchno-issledovatel'skikh inkubatorov. [Proceedings of the All-Russian conference of student research incubators]. Tomsk, 2014, $180 \mathrm{p}$.

10. Trofimchuk D. A., Yermoshkin Y. M., Kochev Y. V. et al. [Electrostatic discharge problem in geostationary spacecraft electrojet propulsion subsystem]. Vestnik SibGAU. 2015, Vol. 16, No. 2, P. 404-410 (In Russ.).
11. Novikov L. S., Babkin G. V. et al. Kompleksnaya metodologiya opredeleniya parametrov elektrostaticheskoy zaryadki, elektricheskikh poley i proboyev na kosmicheskikh apparatakh $v$ usloviyakh ikh radiatsionnoy elektrizatsii. [Complex methodology of determination of parameters electrostatic charging, electric fields and discharges on space craft in radiation electrization conditions], Moscov, Izd-vo TsNIImash Publ., 1995, 160 p.

12. Purvis C. K., Garret H. B. et al. Design guidelines for assessing and controlling spacecraft charging effects, NASA-T3-2361, 1984, 44 p.

13. Maximov I. A., Grafodatsky O. S. et al. [Results of research of spacecraft interference immunity during spacecraft charging impact and protection methods]. Nauchno-tekhnicheskiy otchet NTO 434-3645-89. [Scientific and Technical Report]. Krasnoyarsk, NPO PM Publ., $1989,210 \mathrm{p}$.

14. Mileev V. N., Novikov L. S. [Physicomathematical model of spacecraft charging on GEO and HEO. Research on geomagnetism]. Issledovaniya po geomagnetizmu, aeronomii i fizike Solntsa. 1989, Iss. 86, P. 64-98 (In Russ.).

15. Garret H. B., Spitale Guy C. Magnetospheric Plasma Modeling (0-100 keV). Journal of Spacecraft and Rockets. 1985, Vol. 22, No. 3, P. 231-244.

\section{Библиографические ссылки}

1. Максимов И. А., Кочура С. Г. Исследование влияния факторов космического пространства и техногенных факторов на космические аппараты, разработка методов и средств защиты : монография / Сиб. гос. аэрокосмич. ун-т. Красноярск, 2011. 182 с.

2. ECSS-E-ST-20-06C. Космическое проектирование. Электризация космических аппаратов. Стандарт / Европейское космическое агентство. 2008. 120 с.

3. Модель космоса. В 2 т. Т. 2. Воздействие космической среды на материалы и оборудование космических аппаратов / под ред. М. И. Панасюка, Л. С. Новикова. М. : КДУ, 2007. 1144 с.

4. Наземные стендовые испытания космических аппаратов на стойкость к воздействию радиационной электризации / О. С. Графодатский [и др.] // Руководство для конструкторов / ЦНИИМаш, ГОНТИ-1. 1992. $157 \mathrm{c}$.

5. NASA-HDBK-4002A. Mitigating in-space charging effects - a guideline. NASA, 2011. $181 \mathrm{p}$.

6. MIL-STD-461. Requirements for the control of electromagnetic interference characteristics of subsystems and equipment. US Department of Defense. 1999.

7. Garret H. B. The geosynchronous plasma environment. AIAA Paper 90-0289, 1999. 16 p.

8. Исследование характеристик электрических полей от электростатических разрядов / Р. Е. Тихомиров [и др.] // Вестник СибГАУ. 2016. Т. 17, № 4. С. 1015-1019.

9. Моделирование радиационной электризации конструкционных материалов космических аппаратов / Р. Е. Тихомиров [и др.] // Тр. Всерос. конф. студенческих научно-исследовательских инкубаторов (15-17 мая 2014, г. Томск) / под ред. В. В. Демина. Томск : Изд-во НТЛ, 2014. 180 с. 
10. Проблема электростатических разрядов в электрореактивной двигательной подсистеме геостационарного космического аппарата / Д. А. Трофимчук [и др.] // Актуальные вопросы проектирования автоматических космических аппаратов для фундаментальных и прикладных научных исследований / сост. В. В. Ефанов. Химки : Изд-во ФГУП «НПО имени С. А. Лавочкина», 2015. С. 285-289.

11. Комплексная методология определения параметров электростатической зарядки, электрических полей и пробоев на космических аппаратах в условиях их радиационной электризации / Л. С. Новиков [и др.]. М. : Изд-во ЦНИИмаш, 1995. 160 с.

12. Пурвис К. К., Гаррет Г. Б. Указания по проектированию КА для оценки и контроля эффектов электризации // NASA-T3-2361, 1984, перевод рег. ном. 04509243ю 1986.47 c.
13. Результаты исследования помехоустойчивости КА к воздействию факторов электризации и отработки средств защиты / И. А. Максимов [и др.] // Научнотехнический отчет НТО 434-3645-89. Красноярск : НПО ПМ, 1989. 210 с.

14. Милеев В. Н., Новиков Л. С. Физикоматематическая модель электризации ИСЗ на геостационарной и высокоэллиптической орбитах // Исследования по геомагнетизму, аэрономии и физике Солнца. М. : Наука, 1989. Вып. 86. С. 64-98.

15. Magnetospheric Plasma Modeling $(0-100 \mathrm{keV}) /$ H. B. Garret, Guy C. Spitale // Journal of Spacecraft and Rockets. 1985. Vol. 22, No. 3. P. 231-244.

(C) Tikhomirov R. E., Maximov I. A., Trofimchuk D. A., Ivanov V. V., Balashov S. V., 2018 